\title{
Trichinellosis IN the Slovak RepUblic
}

\author{
DUBINSKÝ P.*, ŠTEFANČ́́KOVÁ A.*, KINČEKOVÁ J.*, ONDRISKA F.**, \\ REITEROVÁ K. \& MEDVEĎOVÁ M.*
}

\begin{abstract}
Summary :
The occurrence of trichinellosis in farm or wildlife animals in some areas pose the permanent risk of infection in humans. In Slovakia, where only the sylvatic trichinellosis exists, the humans trichinellosis is sporadic. The most common cause of infection is wild boar meat. Unusual local eating customs may also favour an outbreak of disease in humans. The outbreak of trichinellosis in Slovakia in 1998, when 336 people were affected, was of the same kind. Trichinella britovi was the agent of the infection.
\end{abstract}

KEY WORDS : trichinellosis, epidemiology, outbreak, Slovak Republic.

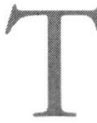
richinellosis in humans occurs sporadically despite the veterinary safety regulations for food of animal origin in most countries. The extent of outbreaks varies, and also depends on regional and national eating habits. Most commonly people get infected after consumption of wild boar meat, but on the other hand, atypical sources of infection have also been recorded, e.g. red fox meat (Pozio, 1998). Hörning (1965) presented the review of infection sources of trichinellosis in humans in Switzerland. In 1936 five people were infected with coypu meat. In 1938, 1954 and 1955 overall thirteen people were infected with dog meat, one patient died three months after clinical symptoms appeared.

Trichinellosis in humans is rare in Slovakia. During 1962-1999 nine outbreaks were observed. All outbreaks happened in the region of Eastern Slovakia. The source of the infection usually was Trichinella larvae containing meat of wild boards, or meat of pigs fed with offal of wild boar and/or carnivore (Dubinský et al., 1994).

Prevalence of trichinellosis in Slovakia in free-living carnivores in years 1954-1956 was relatively high. The most infected animals were lynx $(66.67 \%)$, wolf $(33.33 \%)$, red fox $(27.03 \%)$ and wild cat (15.79\%). 82 dogs and 95 wild boars were examined and were

\footnotetext{
* Parasitological Institute of the Slovak Academy of Sciences, Hlinkova 3, 04001 Košice, Slovak Republic.

** HPL, GmbH, Bratislava, Slovak Republic.

Correspondence: Pavol Dubinský.

Tel.: + 421956334455 - Fax.: +421956331414.

E-mail: dubinsky@saske.sk
}

confirmed negative (Mituch, 1957). Subsequently, significantly low prevalence was recorded in wolf $(7.1 \%)$ and red fox (3.18\%) in years 1987-1993. All examined dogs (28) were negative. Trichinellosis was also found in wild boars (0.2\%) (Dubinský et al., 1998a). Above mentioned data suggest that only sylvatic cycle of trichinellosis exists in Slovakia. Sylvatic trichinellosis exists in the region of the village Valaská where the outbreak of trichinellosis occurred in 1998. Only two cases of trichinellosis in humans had been observed in this region during 1987-1996 (Dubinský et al., 1998b).

\section{MATERIAL AND METHODS}

T pidemiological situation in the whole area of Slovak Republic was observed between 19952000. Muscle samples of wild boars, red foxes, brown bears and small rodents were examined by the digestion method for the presence of Trichinella larvae. Sera of people suspected for trichinellosis were examined by ELISA method using the antigen of $T$. spiralis larvae. The same method was employed to examine the presence of anti-Trichinella antibodies in sera of dogs and small rodents (Havasiová \& Dubinský, 1994).

\section{RESULTS}

E xamination of wild boars for the presence of Trichinella larvae during years 1995-1996 showed that out of the total 19,737 examined wild boars 43 were positive (prevalence $0.22 \%$ ). The examination of 334 red foxes in year 2000 proved that 19 red foxes were positive (prevalence $5.7 \%$ ). Out of 2,307 suspected patients examined for trichinellosis over the last five years, a total of 373 were positive. 336 patients from the total numbers were infected after consumption of smoked sausages at Valaská village. It is the biggest outbreak of trichinellosis in the Slovak Republic until now. 
Sausages are traditionally made in this village just once a year for the folk festival at the end of a carnival season. Those sausages were consumed in the second half of February by participants and accidental guest of the carnival and were spread in this way to other regions of Slovakia. The majority of individuals proved as infected, showed no intestinal symptoms of trichinellosis and symptoms of tissue migration of larvae were attributed to influenza since a flu epidemic was just peaking in the region. Trichinellosis was diagnosed only on April 17, when Trichinella larvae were identified in sausages. Consequently, dog meat used for sausage making was identified and presence of Trichinella larvae was detected.

These larvae were identified as Trichinella britovi (E. Pozio, Rome reference center).

The total number of infected people was 336. Out of 291 positive men, the majority was aged $21-40$. Most of women were $31-50$ years old (Table I). Only 73 patients were from regions outside the focus of the outbreak (Ondriska et al., 1999). Data clearly suggest that the village celebration was predominantly made by middle-aged men; in patients outside of the focus of the outbreak, differences between sexes were statistically insignificant. This extensive outbreak has settled without any fatal case.

Since the patients were serologically examined only 8-12 weeks after the probable infection, IgA and IgM antibodies were present in low titres. IgG antibodies were in high and very high titres.

The outbreak created a hazard of a subsequent domestic cycle of trichinellosis at the outbreak focus, considering the extent of the carnival and the number of people affected. Anti-Trichinella antibodies were detected in $66.7 \%$ of the 60 dogs examined. In five of them a digestion method confirmed the presence of Trichinella larvae. Antibodies were also found in $23.8 \%$ of 21 micromammals caught in the outbreak focus. Despite these facts no case of trichinellosis in pigs was recorded in the village Valaská in the following years (1999, 2000).

\section{DISCUSSION}

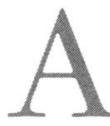

lthough people have negative attitude towards some folk customs, whatever their reasons are, those customs last over many generations. The consumption of sausages containing dog meat was established at Valaská. It prevailed in this region in spite of Slovak laws, which excluded dog meat as well as other kinds of meat from some animals from the food list suitable for consumption.

Many authors proved the occurrence of trichinellosis in dogs. Podhájecký \& Tomašovičová (1969) experimentally caused trichinellosis in a dog. Smith \& Snowdown (1988) detected Trichinella larvae in three Labradors. Similarly, Pozio et al. (1996) discovered that $1 \%$ out of stray dogs were positive in areas over 500 metres above sea level in France. In lower areas that dogs were negative.

The outbreak course of trichinellosis at Valaská has some pecularities distinguishing it from others similar outbreaks. Most of all, it is the source of infection, the dog meat added to sausages. The other characteristic was the unequal distribution of Trichinella larvae $2.6 \pm 1.9 \mathrm{LPG}$ in smoked sausages, whereas the average count of larvae was low (Dubinský et al., 1998b). The clinical symptoms of intestinal phase of trichinellosis did not appear as a consequence of the small number of received larvae. This finding clarifies late detection of clinical symptoms in most patients. A peculiar fact is that mostly men in active age were infected and points out that a traditional way of preparation and even occasional collective consumption of dog sausages could represent a risk in this region.

\begin{tabular}{|c|c|c|c|c|c|c|c|}
\hline \multirow[b]{2}{*}{$\begin{array}{l}\text { Age } \\
\text { Years }\end{array}$} & \multicolumn{3}{|c|}{ Men and women } & \multicolumn{2}{|c|}{ Men } & \multicolumn{2}{|c|}{ Women } \\
\hline & Exam. & Posit. & $\begin{array}{l}\% \text { of total } \\
\text { positivity }\end{array}$ & Posit. & $\begin{array}{l}\% \text { of total } \\
\text { positivity }\end{array}$ & Posit. & $\begin{array}{l}\% \text { of total } \\
\text { positivity }\end{array}$ \\
\hline $1-15$ & 65 & 20 & 5.95 & 13 & 4.47 & 7 & 15.56 \\
\hline $16-20$ & 122 & 47 & 13.99 & 39 & 13.40 & 8 & 17.78 \\
\hline $21-30$ & 232 & 90 & 26.79 & 84 & 28.87 & 6 & 13.33 \\
\hline $31-40$ & 243 & 84 & 25.00 & 71 & 24.40 & 13 & 28.89 \\
\hline $41-50$ & 191 & 63 & 18.75 & 53 & 18.21 & 10 & 22.22 \\
\hline $51-60$ & 77 & 23 & 6.84 & 22 & 7.56 & 1 & 2.22 \\
\hline$>61$ & 22 & 9 & 2.68 & 9 & 3.09 & 0 & - \\
\hline Total & 952 & 336 & 100 & 291 & 100 & 45 & 100 \\
\hline
\end{tabular}

Table I. - Outbreak of human trichinellosis in the Slovak Republic in 1998. 


\section{ACKNOWLEDGEMENTS}

This work was supported by Science Grant Agency of Slovak Republic VEGA, grant No. $2 / 5012 / 98$. The authors are grateful to Dr. I.

Beer and Dr. D. Budajová from Rooswelt's Hospital in Banská Bystrica and members of State Veterinary Department of the Slovak Republic, Bratislava.

\section{REFERENCES}

DubinskÝ P., ŠTEFanČííová A., HovorKa J. \& MitTerpaK J. Epidemiology of trichinellosis in Slovakia, in: Trichinellosis. Campbell W. C., Pozio E. \& Bruschi F. (Eds), Instituto Superiore di Sanita Press, Rome, 1994, 515-520.

DubinsKÝ P., SOKOL J., DVORoŽŇaKová E., ŠTEFANČIKOVÁ A., REITEROVÁ K., KinČEKOVÁ J., ŠVRČEK Š. \& ĎUROVE A. Epidemiology of trichinellosis in Slovakia. Slovak Veterinary Journal, 1998a, 23, 120-125 (In Slovak)

Dubinský P., TOMašovičová O., Reiterová K., Kinčeková J., RaKicKÝ P., SOLAR J. \& ŠPaKUlová M. Epidemiology of trichinellosis in Valaská. Slovak Veterinary Journal, 1998b, 23, 204-207 (In Slovak)

HöRNIG B. Weitere Trichinenfunde in der Schweiz. Schweizer Archiv für Trierheilkunde, 1965, 107, 335-340.

Havasioví K. \& DubinsKÝ P. Antibody response during the course of human trichinellosis, in: Trichinellosis. Campbell W. C., Pozio E. \& Bruschi F. (Eds), Instituto Superiore di Sanita Press, Rome, 1994, 331-344.

Mutich J. Free-living carnivores as carriers of trichinellosis in natural environment, in: Helminthologia, Hovorka J. (Ed), Slovak Academy of Sciences Press, Bratislava, 1957, 104-109.

OndRiska F., Pochybová M., Kultan V., SMIĚ̌na A., LesŇaková M., Dañová K., Mihal' ková V., Duliková M., Kuchtová M., LišKa M. \& Streharová A. Regional incidence of human trichinellosis outside the outbreak focus. Helminthologia, 1999, 37, 67-70.

PODHAJECKÝ K. \& TOMAŠOVIČOVA O. Intrauterine infection with Trichinella. Biologia (Bratislava), 1969, 24, 623-628.

Pozıo E. Trichinellosis in the European Union: Epidemiology, ecology and economic impact. Parasitology Today, 1998, 14, 35-38.

Pozio E., la Rosa G., Serrano F. J., Barrat J. \& Rossi L. Environmental and human influence on the ecology of Trichinella spiralis and Trichinella britovi in Western Europe. Parasitology, 1996, 113, 527-533.

Smith H. J. \& SNowdown K. E. Sylvatic Trichinellosis in Canada. Canadian Journal of Veterinary Research, 1988, 52, 448-449. 